\title{
Identification of Fusobacterium species by the electrophoretic migration of glutamate dehydrogenase and 2-oxoglutarate reductase in relation to their DNA base composition and peptidoglycan dibasic amino acids
}

\author{
S. E. GHARBIA and H. N. SHAH
}

\section{Department of Oral Microbiology, The London Hospital Medical College, Turner Street, Whitechapel, London E1 2AD}

\begin{abstract}
Summary. Rapid identification of Fusobacterium spp. is hampered by their inability to ferment carbohydrates and the availability of relatively few useful phenotypic characters. In an attempt to identify new diagnostic markers for species, we reported recently the potential utility of glutamate dehydrogenase (GDH) electrophoretic mobilities for distinguishing eight species of Fusobacterium. We have extended these observations to include all recognised members of the genus except $F$. prausnitzii and $F$. perfoetens, and our results show that they cluster into three broad electrophoretic groups. Some species, such as $F$.periodonticum, $F$. simiae and $F$.necrophorum, possessed GDH with similar electrophoretic mobilities. However, within such clusters, the electrophoretic migration of 2-oxoglutarate reductase (OGR) distinguished between species. Neither GDH or OGR mobility alone clearly differentiated all species, but their combined use provided unambiguous discrimination of all species except $F$. varium and $F$. mortiferum. The DNA base compositions of all species except $F$. naviforme (ATCC 25832) and $F$. sulci, were within the range $26-34 \mathrm{~mol} \%$ $\mathrm{G}+\mathrm{C}$, suggesting the genus may be homogeneous. However, the peptidoglycan composition divided the genus into two major groups that contained either lanthionine or diaminopimelic acid; $F$. mortiferum peptidoglycan contained both dibasic amino acids.
\end{abstract}

\section{Introduction}

Fusobacterium spp. are now frequently reported in clinical specimens and appear to form a significant component of the bacterial flora in mixed anaerobe infections. ${ }^{1}$ In man, examples of such infections include necrotic tonsillitis, oral and dental infections, brain abscesses, empyma, hepatic and intra-abdominal abscesses and endocarditis. ${ }^{1}$ Infections in animals vary widely and include liver abscesses in cattle ${ }^{2}$ and foot rot in sheep. ${ }^{2}$ However, the clinical importance of these organisms is perhaps still not fully appreciated as their identification is largely overlooked in most diagnostic laboratories.

Received 12 Feb. 1990 ; accepted 30 April 1990.
Traditional methods of identification, which rely largely on carbohydrate fermentation reactions, are of limited value because Fusobacterium spp. are generally non-fermentative. Consequently several alternative approaches have been used. At the genus level, all species are characterised by the production of butyric and acetic acids as major end products of metabolism ${ }^{1,2}$ and their cellular fatty acids comprise predominantly straight-chain and mono-unsaturated fatty acids. ${ }^{3}$ Polypeptide analysis by sodium dodecylsulphate-polyacrylamide gel electrophoresis has been investigated extensively; however, the electrophoretic patterns derived were too complex and inconsistent within a species for routine identification. ${ }^{4}$ Pyrolysis-mass spectrometry of whole cells of Fusobacterium has recently been employed ${ }^{5}$ but, with few exceptions, isolates of most species were assigned in several clusters of the dendrogram. 
The electrophoretic mobility of glutamate dehydrogenase $(\mathrm{GDH})$ has been reported in eight species of Fusobacterium. ${ }^{6}$ However, application of this method to study other species, such as $F$.alocis, $F$. peridonticum, $F$. simiae, $F$. sulci and F. ulcerans, resulted in similar electrophoretic migration of enzymes from several species. Here we report the electrophoretic mobility of another enzyme, 2oxoglutarate reductase (OGR) and show that the combined use of these enzymes can be applied to identify most species. Furthermore, we examined the possible correlation of these data with the heterogeneity in peptidoglycan composition and we also report the guanine plus cytosine $(\mathrm{mol} \% \mathrm{G}+\mathrm{C}$ ) content of the DNA of all strains used in this study.

\section{Materials and methods}

\section{Bacterial strains}

The Fusobacterium strains used in this study and their sources are given in table $\mathrm{I}$.

\section{Growth conditions and preparation of cell-free extracts}

All strains were maintained by weekly subculture on Blood Agar Base (Oxoid) containing sheep blood (Oxoid) $5 \%$ in an atmosphere of $\mathrm{Co}_{2} 10 \%, \mathrm{H}_{2} 10 \%, \mathrm{~N}_{2} 80 \%$ at $37^{\circ} \mathrm{C}$. Cell-free extracts were prepared as described previously. ${ }^{7}$ Briefly, cells were harvested from 24 -h bloodagar cultures and were suspended in $0.5 \mathrm{ml}$ of $100 \mathrm{mM}$

Table I. Sources of Fusobacterium strains

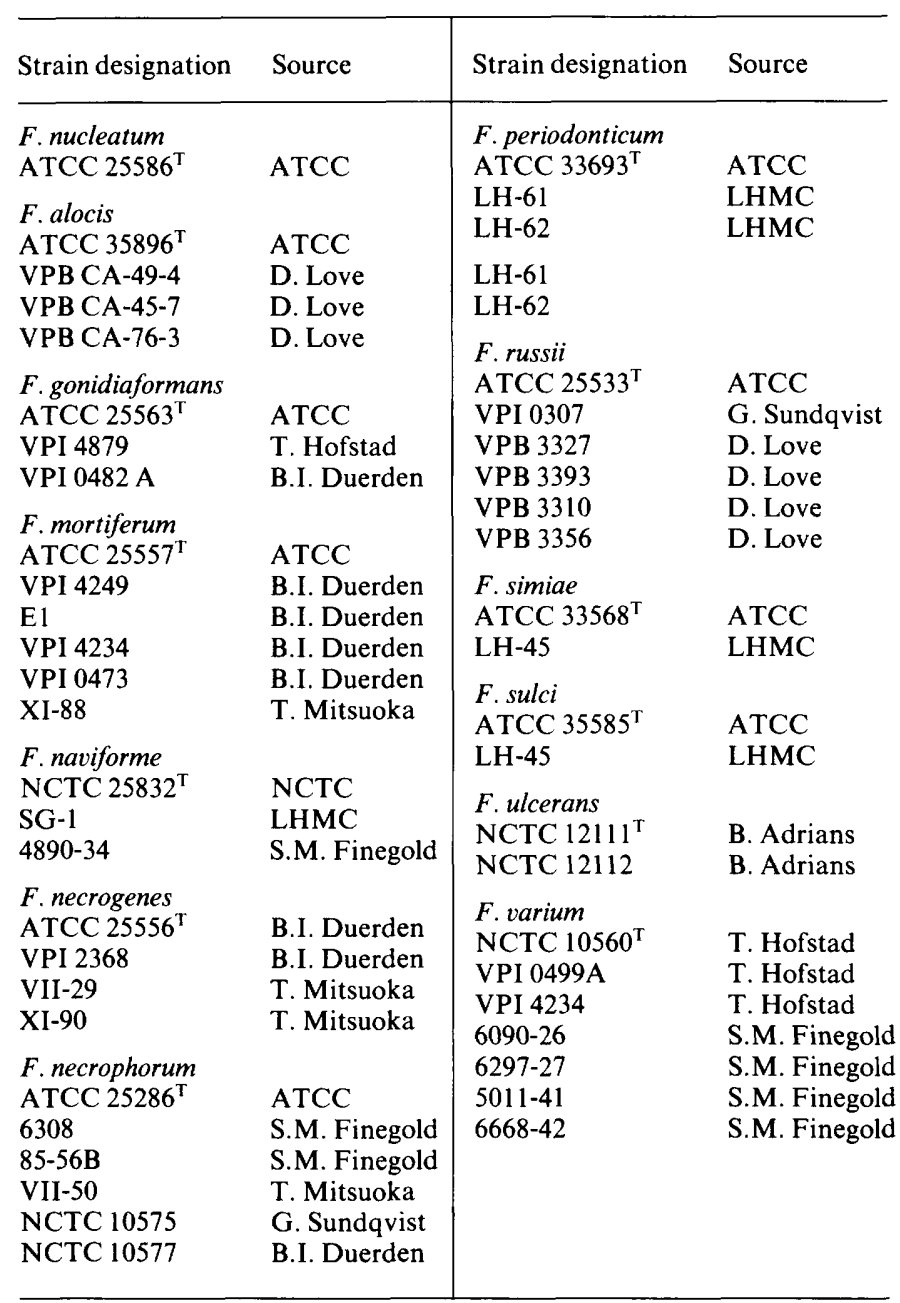

ATCC, American Type Culture Collection; NCTC, National Collection of Type Cultures; LHMC, The London Hospital Medical College; T, type strain. 
tris(hydroxymethyl)aminomethane $\mathrm{HCl}$ buffer ( $\mathrm{pH} \mathrm{8.5).}$ Each cell suspension was shaken with Ballotini beads (grade 12) for $10 \mathrm{~min}$ in a Mickle tissue disintegrator at $4^{\circ} \mathrm{C}$. The suspension was centrifuged at $37000 \mathrm{~g}$ for $10 \mathrm{~min}$, and the supernates were used immediately for electrophoresis.

\section{Electrophoresis and staining of the enzymes}

Cell-free extracts were subjected to electrophoresis for $90 \mathrm{~min}$ at $15 \mathrm{~V} / \mathrm{cm}$ on $5.7 \times 14-\mathrm{cm}$ Cellogel support strips with $4 \mathrm{~mm}$ barbitone-acetic acid buffer (pH 8.6). GDH was visualised by staining with a solution of $(/ \mathrm{L})$ glutamate $20 \mathrm{~g}$, nicotinamide adenine dinucleotide $5 \mathrm{~g}$, phenazine methosulphate $4 \mathrm{~g}$, and thiazolyl blue tetrazolium $0.02 \mathrm{~g}$ in $100 \mathrm{~mm}$ Tris(hydroxymethyl)aminomethane- $\mathrm{HCl}$ buffer (pH 9-0). 2-Oxoglutarate reductase was visualised by replacing the glutamate with a solution of 2hydroxyglutarate $10 \mathrm{~g} / \mathrm{L}$.

\section{Isolation, purification and determination of base composition of DNA}

DNA was purified by the method of Marmur. ${ }^{8}$ The DNA base composition was estimated from its melting temperature in SSC with a Gilford (model 240) spectrophotometer and a Gilford 2527 thermal programmer as described previously. ${ }^{7}$

\section{Preparation and examination of cell walls}

Cell walls were prepared and hydrolysed by the method of Schleifer and Kandler. ${ }^{9}$ The dibasic amino acids of the mucopeptides were analysed qualitatively by descending chromatography on Whatman No. 1 paper with methanol:pyridine:concentrated $\mathrm{HCl}$ : water $(80: 20$ : $2 \cdot 5: 17 \cdot 5)$ as running solvent. Amino acids were identified by reference to authentic standards and by their distinctive colours when treated with ninhydrin $0.25 \%$ in acetone containing glacial acetic acid $7 \%{ }^{7}$

\section{Results}

Representative strains of 13 species of Fusobacterium all possessed high levels of GDH and OGR such that only $1 \mu \mathrm{l}$ of a cell-free extract $\left(c .10^{6}-10^{8}\right.$ cells $/ \mathrm{ml}$ ) was sufficient to detect both enzymes reliably after electrophoresis. Both enzymes required NAD for substrate oxidation but their $\mathrm{pH}$ range for activity differed. GDH was stained over a wide $\mathrm{pH}$ range $(c .7 \cdot 5-10 \cdot 5)$, whereas OGR was visualised within a narrower $\mathrm{pH}$ range $(c .8 \cdot 5-9 \cdot 0)$. $F$.nucleatum, F.russii, F.gonidiaformans and $F$. ulcerans had characteristic GDH electrophoretic mobilities, but enzyme analysis clustered the remaining species into three broad groups. $F$. periodonticum, $F$. simiae and $F$. necrophorum had similar GDH mobilities of $3.0-3.6 \mathrm{~cm}$; the GDH extracted for $F$. varium, $F$. mortiferum, $F$. alocis and the type strain of $F$. naviforme co-electrophoresed at $3.9 \mathrm{~cm}$; and the $\mathrm{GDH}$ mobility of $F$. alocis $(2.4 \mathrm{~cm})$ was similar but not identical to that of $F$. necrogenes $(2.6 \mathrm{~cm})$ (fig. 1). Within these clusters, the electrophoretic mobility of OGR provided a further means of distinguishing species, e.g., $F$. alocis and $F$. necrogenes, which had similar GDH mobilities, were distinguished readily by the migration distances of OGR.

The type strain of $F$. naviforme had electrophoretic mobilities of $4 \cdot 1 \mathrm{~cm}$ for GDH and $5 \cdot 2 \mathrm{~cm}$ for OGR, but the three clinical isolates examined had mobilities of 2 and $2.6 \mathrm{~cm}$ for GDH and OGR respectively. Furthermore, the dibasic amino acid of the peptidoglycan of the type strain contained diaminopimelic acid, whereas that of the three clinical strains had lanthionine (fig. 1; table II). Of the species tested, only $F$. naviforme showed heterogeneity in peptidoglycan composition (table II).

The DNA base composition of all species was within the range $25-34 \mathrm{~mol} \% \mathrm{G}+\mathrm{C}$, except for F. sulci $(39 \%)$ and the type strain of F. naviforme, ATCC $25832(49 \%)$ (table II). Clinical isolates which were phenotypically very similar to $F$. naviforme had DNA base compositions of 32 $33 \mathrm{~mol} \% \mathrm{G}+\mathrm{C}$ (table II). The peptidoglycan composition divided the genus into two distinctive groups, those species that contained diaminopimelic acid ( $F$. naviforme, $F$. sulci, $F$. ulcerans and $F$.varium) and that also possessed GDH with mobilities of $4-7 \mathrm{~cm}$, and species that contained lanthionine and had GDH mobilities $<4 \mathrm{~cm}$. $F$. mortiferum was atypical in possessing both dibasic amino acids; it clustered with the highGDH-mobility group. Fig. 1 gives an overview of these inter-relationships.

\section{Discussion}

Previously, we reported the importance of glutamate as an energy source for Fusobacterium spp. and showed its rapid uptake from a chemically defined medium. ${ }^{10}$ The presence of both GDH and OGR, catabolic enzymes of glutamate metabolism, in Fusobacterium spp. further supports these physiological findings. The broad $\mathrm{pH}$ range of activity for GDH (c. 7-10) enables this enzyme to be stained readily in most electrophoretic systems. However, similarity in migration distances of GDH of some species such as $F$. alocis $(2.4 \mathrm{~cm})$ and $F$. necrogenes $(2.6 \mathrm{~cm})$ limits its use in identifying species. Enzymes which migrate closely can be mixed and electrophoresed together to distinguish between 


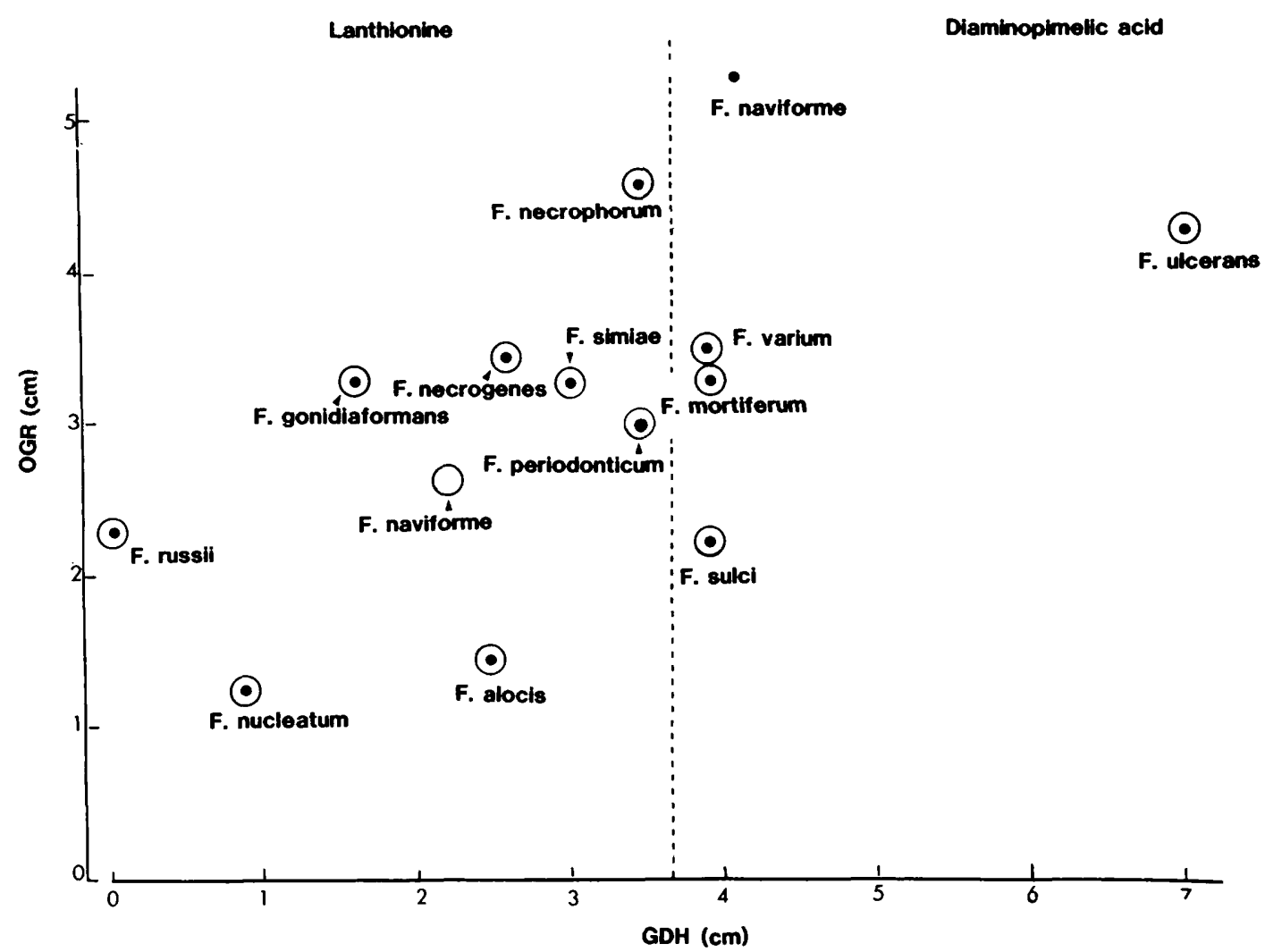

Fig. 1. Electrophoretic mobilities of GDH and OGR in reference and clinical strains of Fusobacterium (@), clinical strains of $F$. naviform $(O)$ and the type strain of $F$. naviforme $(\mathcal{O})$, and the distribution of peptidoglycan dibasic amino acids among $F u$ sobacterium spp. Species with higher GDH mobilities had diaminopimelic acid whereas those with slower migrating enzymes had peptidoglycans containing meso-lanthionine.

them, but ideally, the application of another enzyme mobility which differs significantly between the species should be employed. In a previous study, we screened for several enzymes involved in nitrogen metabolism of Fusobacterium spp. The first enzyme which was present in all species and reliably corroborated the GDH patterns was OGR. Thus, the three GDH electrophoretic patterns of $F$. nucleatum ${ }^{6}$ were recently confirmed by OGR patterns in more than 30 human isolates. ${ }^{11}$

The GDH electrophoretic mobility of eight species of Fusobacterium has been reported. ${ }^{6}$ This study extends these findings to five further species $F$. alocis, F. periodonticum, $F$. sulci, $F$. ulcerans and $F$. simiae - and emphasises the importance of GDH as a diagnostic marker at both the generic and species level. Although its potential value for delineating all Fusobacterium spp. has been restricted by common electrophoretic mobilities in some species (fig. 1), a combination of the electrophoretic migration of GDH and OGR provided diagnostic patterns that can be used to distinguish all Fusobacterium spp. except F.varium and F. mortiferum.

In an earlier study, Love et al. ${ }^{12}$ reported that although clinical isolates of $F$. naviforme were phenotypically similar to the type strain, there was negligible DNA-DNA homology between the type strain and clinical isolates. In this study, we have shown that their dibasic amino-acid composition and enzyme electrophoretic profiles also show a high degree of discordance (fig. 1). Thus, clinical isolates that resemble phenotypically the type strain of $F$. naviforme (a rodent isolate) differ markedly from the type strain and warrant placement in new species. The name $F$. asaccharolyticum is tentatively proposed.

The genus Fusobacterium has been shown to be heterogeneous in peptidoglycan composition. ${ }^{13-15}$ Species such as $F$. nucleatum and $F$. necrophorum possess a directly cross-linked peptidoglycan, based upon the sulphur-containing dibasic amino acid 
Table II. DNA base compositions and dibasic amino acids of the peptidoglycan of reference and clinical strains of Fusobacterium species

\begin{tabular}{|c|c|c|}
\hline Species & $\mathrm{Mol} \% \mathrm{G}+\mathrm{C}$ & Dibasic amino acid \\
\hline $\begin{array}{l}\text { F. nucleatum } \\
\text { ATCC } 25586\end{array}$ & 26 & meso-lanthionine \\
\hline $\begin{array}{l}\text { F. alocis } \\
\text { ATCC } 35896 \\
3 \text { clinical isolates }\end{array}$ & $\begin{array}{c}34 \\
32-34\end{array}$ & " \\
\hline $\begin{array}{l}\text { F. gonidiaformans } \\
\text { ATCC } 25563 \\
3 \text { reference strains }\end{array}$ & $\begin{array}{c}33 \\
31-33\end{array}$ & $"$ \\
\hline $\begin{array}{l}\text { F. necrogenes } \\
\text { ATCC } 25556 \\
3 \text { clinical strains }\end{array}$ & $\begin{array}{c}28 \\
27-28 \cdot 7\end{array}$ & $"$ \\
\hline $\begin{array}{l}\text { F. necrophorum } \\
\text { ATCC } 25286 \\
5 \text { clinical isolates }\end{array}$ & $\begin{array}{c}32 \\
32-35\end{array}$ & ", \\
\hline $\begin{array}{l}\text { F. periodonticum } \\
\text { ATCC } 33693 \\
2 \text { clinical isolates }\end{array}$ & $\begin{array}{c}28 \\
27-28 \cdot 1\end{array}$ & $"$ \\
\hline $\begin{array}{l}\text { F. russii } \\
\text { ATCC } 25533 \\
5 \text { clinical isolates }\end{array}$ & $\begin{array}{c}26 \\
24-26\end{array}$ & $"$ \\
\hline $\begin{array}{l}\text { F. simiae } \\
\quad \text { ATCC } 33568 \\
\text { 1 clinical isolate }\end{array}$ & $\begin{array}{l}28 \\
28\end{array}$ & ", \\
\hline $\begin{array}{l}\text { F. sulci } \\
\text { ATCC } 35585\end{array}$ & 39 & $\begin{array}{l}\text { Diaminopimelic } \\
\text { acid }\end{array}$ \\
\hline $\begin{array}{l}\text { F. ulcerans } \\
\text { NCTC } 12111 \\
1 \text { reference strain }\end{array}$ & $\begin{array}{c}25 \\
25 \cdot 4\end{array}$ & " \\
\hline $\begin{array}{l}\text { F. varium } \\
\text { NCTC } 10560 \\
6 \text { clinical strains }\end{array}$ & $\begin{array}{c}26 \\
25-26\end{array}$ & $"$ \\
\hline $\begin{array}{l}\text { F. naviforme } \\
\text { ATCC } 25832 \\
2 \text { clinical strains }\end{array}$ & $\begin{array}{c}49 \\
32-33\end{array}$ & meso-lanthionine \\
\hline $\begin{array}{l}\text { F. mortiferum } \\
\text { ATCC } 25557 \\
6 \text { clinical isolates }\end{array}$ & $25-26 \cdot 5$ & $\begin{array}{l}\text { meso-lanthionine } \\
\text { and } \\
\text { diaminopimelic acid }\end{array}$ \\
\hline
\end{tabular}

Details of strains listed as clinical or reference strains are given in table I.

lanthionine. ${ }^{15}$ Fig. 2 shows the nature of the linkage. The mucopeptide of several other species, such as $F$. varium, contains diaminopimelic acid as its sole dibasic amino acid. ${ }^{13}$ Interestingly, we observed in the present study that species which belonged to the slower GDH-OGR mobility cluster possessed lanthionine whereas those with faster enzyme mobilities had a peptidoglycan based on diaminopimelic acid (fig. 1). F. mortiferum, which contained both dibasic amino acids, showed more similarity with $F$. varium in electrophoretic patterns. This similarity between the latter species has also been confirmed by 5 S-rRNA sequence data ${ }^{16}$ and is presently being compared by $16 \mathrm{~S}-\mathrm{rRNA}$ sequence analysis.

The results of the present study indicate that the combined use of GDH and OGR electrophoretic patterns provide a useful and rapid method for identifying most species of Fusobacterium. Furthermore, both enzymes appear to be useful for preliminary investigations of the natural diversity of species before undertaking such studies as DNADNA hybridisation. With this method, three subgroups of $F$. nucleatum designated Fn-1, Fn-2 and Fn-3 among human oral isolates were resolved and this segregation has been supported by rRNA restriction patterns. ${ }^{17}$ Differences between these groups and animal isolates of $F$.nucleatum led to the recent proposal of four subspecies. ${ }^{18}$ Recognition of these subspecies has facilitated clearer

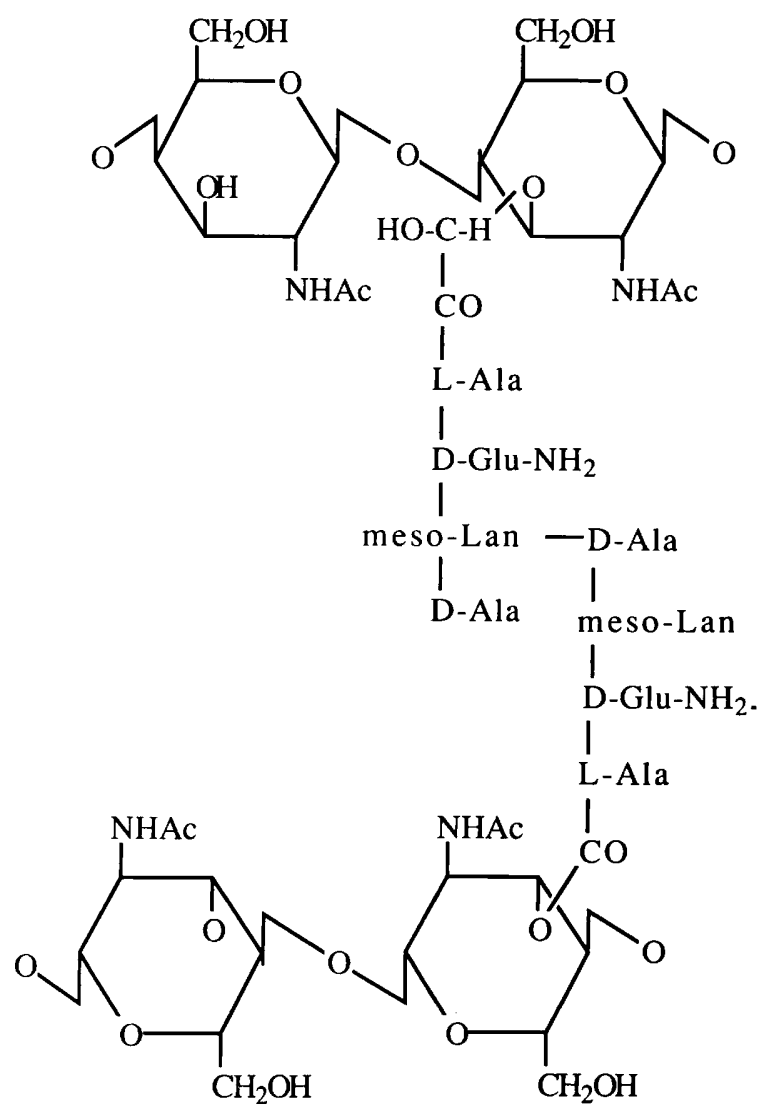

Fig. 2. Nature of the cross-linkage of the meso-lanthioninecontaining peptidoglycan of some Fusobacterium spp. 
discrimination among isolates of $F$. nucleatum and highlighted their possible ecological distribution. Thus, F. nucleatum subsp. nucleatum was shown recently to be more commonly associated with diseased sites, whereas the remaining subspecies were associated with healthy sites in the mouth. ${ }^{19}$

\section{REFERENCES}

1. Finegold SM, George WL, Mulligan ME. Anaerobic infections part 1. Dis Mon XXXI 1985; 31:1-77.

2. Langworth BF. Fusobacterium necrophorum: its characteristics and role as an animal pathogen. Bacteriol Rev 1977; 41:373-390.

3. Jantzen E, Hofstad T. Fatty acids of Fusobacterium species taxonomic implications. J Gen Microbiol 1981; 123: $163-171$.

4. Calhoon DA, Mayberry WR, Slots J. Cellular fatty acid and soluble protein profiles of oral fusobacteria. $J$ Dent Res $1983 ; 62: 1181-1185$.

5. Magee JT, Hindmarch JM, Bennett KW, Duerden BI, Aries RE. A pyrolysis-mass spectrometry study of fusobacteria. J Med Microbiol 1989; 28:227-236.

6. Gharbia SE, Shah HN. Characteristics of glutamate dehydrogenase, a new diagnostic marker for the genus Fusobacterium. J Gen Microbiol 1988; 134:327-332.

7. Shah HN, Williams RAD, Bowden GH, Hardie JM. Comparison of the biochemical properties of Bacteroides melaninogenicus from human dental plaque and other sites. J Appl Bacteriol $1976 ; 41: 473-495$.

8. Marmur J. A procedure for the isolation of deoxyribonucleic acid from microorganisms. J Mol Biol 1961; 3:208218.

9. Schleifer KH, Kandler O. Peptidoglycan types of bacterial cell walls and their taxonomic implications. Bacteriol Revs 1972; 36:407-477.

10. Gharbia SE, Shah HN. The uptake of amino acids from a chemically defined medium by Fusobacterium species. Curr Microbiol 1989; 18: 189-193.

11. Gharbia SE, Shah HN. Glutamate dehydrogenase and 2-oxoglutarate reductase electrophoretic patterns and deoxyribonucleic acid-deoxyribonucleic acid hybridi- sation among human oral isolates of Fusobacterium nucleatum. Int J Syst Bacteriol 1989; 39:467-470.

12. Love DN, Cato EP, Johnson JL, Jones RF, Bailey $M$. Deoxyribonucleic acid hybridization among strains of Fusobacterium isolated from soft tissue infections of cats: comparison with human and animal type strains from oral and other sites. Int J Syst Bacteriol 1987; $37: 23-26$

13. Kato $K$, Umemoto $T$, Fukuhara $H$, Sagawa $H$, Kotani $S$. Variation of dibasic amino acid in the cell wall peptidoglycan of bacteria of the genus Fusobacterium. FEMS Microbiol Lett 1981; 10:81-85.

14. Miyagawa E, Azuma R, Suto T. Peptidoglycan composition of gram-negative obligately anaerobic rods. J Gen Appl Microbiol 1981; 27:199-208.

15. Vasstrand EN, Jansen HB, Miron T, Hofstad T. Composition of peptidoglycans in Bacteroidaceae: determination and distribution of lanthionine. Infect Immun 1982; 36:114-122.

16. Van Den Eynde H, De Baere R, Shah $\mathrm{HN}$ et al. 5Sribosomal ribonucleic acid in Bacteroides and Fusobacterium: evolutionary relationships within these genera and among eubacteria in general. Int $J$ Syst Bacteriol $1989 ; 39: 78-84$.

17. Lawson PA, Gharbia SE, Shah HN, Clark DR. Recognition of Fusobacterium nucleatum subgroups Fn-1, Fn-2 and Fn-3 by ribosomal RNA gene restriction patterns. FEMS Microbiol Lett 1989; 53:41-46.

18. Gharbia SE, Shah HN. Heterogeneity within Fusobacterium nucleatum, proposal of four subspecies. Lett Appl Microbiol 1990; 10: 105-108.

19. Gharbia SE, Shah HN, Lawson PA, Haapasalo M. The distribution and frequency of Fusobacterium nucleatum subspecies in the human oral cavity. Oral Microbiol Immunol $1990 ; 5$, in press. 